\title{
Productivity and nutrient extraction by Brachiaria brizantha fertigated with treated sewage effluent
}

\section{Gilmar Oliveira Santos ${ }^{1 *}$, Rogério Teixeira de Faria ${ }^{2}$, Gilberto Aparecido Rodriguês ${ }^{3}$, Geffson de Figueredo Dantas ${ }^{4}$, Natã Rodriguês Costa ${ }^{5}$}

${ }^{1}$ University of Rio Verde - UniRV, Department of Agronomy and Environment, Rio Verde-GO, Brazil

${ }^{2}$ State University Paulista - UNESP, Department of Rural Engineering, Jaboticabal, SP, Brazil

${ }^{3}$ Faculty of Technology of Taquaritinga - FATEC, Department of Agribusiness, Taquaritinga, SP, Brazil

${ }^{4}$ State University Paulista - UNESP, PhD Student in Soil Science, Jaboticabal, SP, Brazil

${ }^{5}$ State University Paulista - UNESP, Agronomist, Jaboticabal, SP, Brazil

*Corresponding author: gilmar@unirv.edu.br

\begin{abstract}
The present study was performed to evaluate the responses in productivity and nutrient extraction in dry biomass of Brachiaria brizantha 'Marandu' fertigated with treated sewage effluent (TSE) from 2013 to 2014, in Jaboticabal, São Paulo, Brazil. A triple line source sprinkler system was used to perform uniform but gradual irrigation of TSE and mineral fertilization in five treatments, with the following TSE fractions in water: 1.0 (E5); 0.87 (E4); 0.6 (E3); 0.31 (E2), and 0.11 (E1). In addition to fertigation, all treatments were supplemented with $P$ and K. TSE was applied at depths of 1,853 and 2,253 mm year ${ }^{-1}$ in 2013 and 2014, respectively. This provided E5 with the following amounts of $\mathrm{N}, \mathrm{P}, \mathrm{K}$, and $\mathrm{Na}\left(\mathrm{kg} \mathrm{ha}^{-1}\right): 931,27,314$, and 894, in 2013, and 1,132, 21, 463, and 1,428, in 2014. The most relevant effects on $B$. brizantha dry biomass yield and nutrient extraction were obtained with higher doses of TSE. The extract of macronutrients was higher for $\mathrm{K}$ and $\mathrm{N}$, followed by $\mathrm{K}, \mathrm{Ca}, \mathrm{Mg}$, and $\mathrm{Na}$. Based on the responses in productivity and nutrient extraction of soil by the crop as a function of TSE fertilization without soil contamination, we propose that increased fertilizer application be studied further.
\end{abstract}

Keywords: nutrient adsorption rate, wastewater, pasture, irrigation.

Introduction

Forage grasses are important for the efficient and economic feeding of ruminants. Brazil is known worldwide for the production of meat and dairy milk, with pastures used as feed basis. Grassland occupies about 180 million hectares, $21.3 \%$ of the national territory; of these, $70-80 \%$ are Brachiaria forage (RODRIGUÊS, 2004). The predominance of Brachiaria brizantha 'Marandu' is due to its tolerance to low soil fertility, resistance to insects, good leaf-stem ratio, and high yield when properly fertilized and managed.

To ensure efficient and competitive livestock production under grazing conditions, it is necessary to develop soil fertility management strategies to maintain soil productivity and forage quality, providing nutrients in adequate quantities and balanced proportions during efficient and productive pasture processes (Costa et al., 2010). However, for good management, knowledge on crop nutritional requirements is essential, in addition to the potential extraction of nutrients from the soil.

The high costs of agricultural inputs have attracted farmers' attention when adopting sustainable soil fertility management practices. Sewage waters possess macro and micronutrients, which are essential for forage growth (SILVA et al., 2012), and make it possible to increase irrigated areas, even in regions with already compromised water rights. The use of treated sewage effluent (TSE) in the agronomic environment favors an increase in the production and quality of forage by supplying water and nutrition in a sustainable manner.

Fertilization with TSE is assumed to provide better forage development owing to the ready availability of nutrients for the plant, and the split in the application of water and nutrients promotes the absorption of nutrients by the crop, producing better quality material, (SERAFIM and GALBIATTI, 2012). Although in some cases, sodium ( $\mathrm{Na}$ ) is considered to be a beneficial element, since it increases the productivity of some plants (INOCÊNCIO et al., 2014), the technique of fertilization with TSE requires knowledge to avoid soil salinization caused by the excess salts in the TSE.

Nitrogen $(N)$ is the most important element required for the growth of forage plants (PRIMAVESI et al., 2006). Compared with other nutrients, $\mathrm{N}$ has the greatest effect on $B$. brizantha development and its absence limits the production of green mass (COSTA et al., 2010). However, Vilela et al. (1998) states that Brachiaria has a high need for $\mathrm{Na}$, followed by $\mathrm{N}$ and phosphorus (P). 
Costa et al. (2009) evaluated the extraction of macro and micro nutrients as a function of $\mathrm{N}$ (ammonium sulfate and urea) doses (0,100, 200, and $\left.300 \mathrm{~kg} \mathrm{ha}^{-1} \mathrm{y}^{-1}\right)$ in Brachiaria, and observed that the maximum doses of $\mathrm{N}$ led to higher extraction of macro $(\mathrm{K}>\mathrm{N}>\mathrm{Ca}>\mathrm{Mg}>\mathrm{P}=\mathrm{S})$ and micronutrients $(\mathrm{Fe}>\mathrm{Mn}>\mathrm{Zn}>\mathrm{Cu}$ ). In another study, Costa et al. (2008), evaluated the effect of $\mathrm{N}$ and $\mathrm{K}$ doses on the production and extraction of macronutrients by the phytomass of Xaraés grass. Excess nutrients cause non-soil and soil pollution. Crops that export nutrients, such as Brachiaria, are useful to mitigate the risk from soil contamination and groundwater. Costa et al. (2009) also showed that nutrients accumulated in the following decreasing order: $\mathrm{N}=\mathrm{K}>\mathrm{Ca}>\mathrm{Mg}>\mathrm{P}>\mathrm{S}$.

In this study, productivity and nutrient extraction in the dry biomass of $B$. brizantha 'Marandu' fertigated with doses of TSE were evaluated during 2013 and 2014, in Jaboticabal, São Paulo, Brazil.

\section{Results and discussion}

Analysis of the TSE revealed a neutral pH $(7.0 \pm 0.3)$ and medium to high $\mathrm{Na}$ adsorption ratio $(18.0 \pm 2.9)$, with

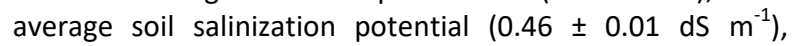
classified as $\mathrm{C}_{2} \mathrm{~S}_{3}$ (Table 3 ).

Annual irrigation depths were 1,853 mm in 2013 and 2,253 $\mathrm{mm}$ in 2014 (Table 4), with precipitation of 1,393 and 721 $\mathrm{mm}$, in the first and second year (Table 2), respectively. High irrigation depths in addition to precipitation were a consequence of the nutritional criterion, in which effluent was applied to meet nutrient crop requirements, even during rainy periods. The amounts of $\mathrm{N}$ applied via TSE are also shown in Table 4; 931 and $1,132 \mathrm{~kg} \mathrm{ha}^{-1}$ of $\mathrm{N}$ was applied in the E5 treatment in 2013 and 2014, respectively. The other treatments received amounts proportional to the application fractions as defined for each treatment (Fig 1).

The following amounts of the remaining nutrients were applied via TSE in treatment $\mathrm{E} 5: \mathrm{P}=27, \mathrm{~K}=314, \mathrm{Ca}=258$, $\mathrm{Mg}=92$ and $\mathrm{Na}=894$, in 2013, and $\mathrm{P}=21, \mathrm{~K}=463, \mathrm{Ca}=358$, $\mathrm{Mg}=108$, and $\mathrm{Na}=1,428 \mathrm{~kg} \mathrm{ha}^{-1}$, in 2014. The other treatments received amounts proportional to the application fractions according to each treatment (Fig 1). Supplemental mineral fertilization with phosphorus $\left(\mathrm{P}_{2} \mathrm{O}_{5}\right)$ and potassium $\left(\mathrm{K}_{2} \mathrm{O}\right)$ was 96 and $554 \mathrm{~kg} \mathrm{ha}^{-1}$, in 2013, and 136 and $696 \mathrm{~kg} \mathrm{ha}^{-1}$, in 2014, respectively.

Brachiaria responded positively to TSE application, as shown by increases in biomass dry weight from 31,260 and 25,736 $\mathrm{kg} \mathrm{ha}^{-1}$ with treatment $\mathrm{E} 1$, to 47,385 and $56,907 \mathrm{~kg} \mathrm{ha}^{-1}$ with treatment E5, in 2013 and 2014, respectively (Table 5). Productivity was higher in summer and spring due to favorable weather conditions (temperature), compared with the sub-optimal temperatures in fall-winter (Table 2). Productivity was higher in 2014, compared with 2013, due to higher temperature and solar radiation in the second year.

Extraction of $\mathrm{N}$ by the Brachiaria increased with increasing doses of applied TSE up to $78.9 \%$, compared with the reference treatment (E3) (Fig 2). The ratio of extracted to applied $\mathrm{N}$ was close to in the range of 180 to $320 \mathrm{~kg} \mathrm{ha}^{-1}$ of applied N. Outside of this range, with either lower or higher $\mathrm{N}$ applications, resulted in a negative soil $\mathrm{N}$ balance, in which extraction was higher than application, as shown by values above the 1:1 line in Fig 2. This effect was caused by the high depletion of soil $\mathrm{N}$, due to low $\mathrm{N}$ application $\left(<200 \mathrm{~kg} \mathrm{ha}^{-1}\right)$ with treatments $\mathrm{E} 1$ and E2, and due to high productivity attained with treatments E4 and E5, despite the high amount of $\mathrm{N}$ applied $\left(>300 \mathrm{~kg} \mathrm{ha}^{-1}\right)$. The increased $\mathrm{N}$ extraction observed with high productivity treatments was a consequence of the high demand for $\mathrm{N}$ by crops for structural components in proteins, enzymes, and to increase productivity, as obtained by Costa et al. (2010).

$\mathrm{N}$ application via TSE was lower in fall-winter (Table 4) compared with the other seasons, due to low crop nutritional demand. This effect resulted in lower biomass productivity in both years (Table 6). Consequently, $\mathrm{N}$ export was reduced (Fig 2), despite higher $\mathrm{N}$ concentration in biomass (Table 6). Conversely, even with reduced $\mathrm{N}$ concentration in biomass, the increased productivity in spring and summer led to higher $\mathrm{N}$ extraction. In both seasons and treatments, a negative $\mathrm{N}$ balance was found $\left(<188.3 \mathrm{~kg} \mathrm{ha}^{-1}\right)$, except with the E3 and E4 treatments during spring of the second year. This marked increase in $\mathrm{N}$ extraction is due to the higher $\mathrm{N}$ uptake at the higher doses. The over-extraction of $\mathrm{N}$ observed in this study might be due to mineralization of the organic matter, which was converted to ammonia and later, by nitrification, to nitrite and, finally, to nitrate (COELHO and MARTINS, 2004). However, Costa et al. (2009) found that $N$ extraction by Marandu grass was increased due to increased dry biomass productivity with a positive $\mathrm{N}$ balance in the soil at doses below $200 \mathrm{~kg} \mathrm{ha}^{-1}$. Our results also indicate that nitrogen replacement should not be applied at fixed doses due to the variation in the response of crop throughout the year.

The results of this study are consistent with those of Primavesi et al. (2006), who evaluated nutrient extraction by Marandu grass subjected to $\mathrm{N}$ levels from 0 to $200 \mathrm{~kg} \mathrm{ha}^{-1}$ per cutting, in a rhodic dystrophic soil in the rainy season; mean $\mathrm{N}$ extraction was $22.9 \mathrm{~kg} \mathrm{~N} \mathrm{t}^{-1}$ of the dry biomass. Coelho and Martins (2004) reported $\mathrm{N}$ extraction from 15.3 to $19.7 \mathrm{~kg} \mathrm{~N} \mathrm{t}^{-1}$ of dry biomass for tropical grasses. Further detailed studies are required to verify the presence of $\mathrm{N}$ fixing bacteria in the soil.

The highest level of $P$ extraction by the crop occurred in 2013 with a higher concentration of foliar P and high dry biomass yield, which was $117 \%$ higher than that applied (Fig 3). In fall-winter, less $P$ was extracted. However, all treatments resulted in extraction that was higher than that applied, except for the E1 treatment in 2014. The summer and spring of 2013 presented similar characteristics with treatments involving high applications of TSE. However, lower productivity was observed with treatments E3, E2, and E1 in the spring, resulting in lower extraction of nutrients. Even with higher application of $\mathrm{K}$ by the crop in the spring of 2014 , nutrient extraction from the soil was lower than in the seasons noted in the previous year.

The excess of $\mathrm{P}$ exported from the soil by the crop was derived from the mineralization of the organic matter, becoming P. Para Monteiro et al. (1995), the omission of P of the Brachiaria cultivation, may compromise the development of forages across in rackets and without lateral tillers.

Because of $P$ supplementation and gradual fertilization, nutrients were extracted homogenously during the same season, except in spring (Table 7).

Primavesi et al. (2006) evaluated the same crop and obtained rhodic $\mathrm{P}$ extraction of only $2.9 \mathrm{~kg} \mathrm{P} \mathrm{t}^{-1}$ by BS. Blum et al. (2012) quantified nutrient removal and nutrients in sugarcane cultivation systems irrigated with TSE up to $150 \%$ 
Table 1. Chemical soil characteristics of the $0-100 \mathrm{~cm}$ layer in the experimental area.

\begin{tabular}{|c|c|c|c|c|c|c|c|c|c|c|c|c|c|c|c|c|}
\hline $\mathrm{PH}$ & OM & $\mathrm{K}$ & $\mathrm{Ca}$ & $\mathrm{Mg}$ & $\mathrm{H}+\mathrm{Al}$ & BS & CEC & $\mathrm{Al}$ & $\mathrm{P}$ & B & $\mathrm{Cu}$ & $\mathrm{Fe}$ & $\mathrm{Mn}$ & $\mathrm{Zn}$ & $\mathrm{S}$ & V \\
\hline & $\mathrm{g} \mathrm{dm}^{-3}$ & \multicolumn{7}{|c|}{ - } & \multicolumn{7}{|c|}{---or } & $\%$ \\
\hline 5.5 & 20 & 4 & 25 & 12 & 27 & 40 & 68 & 0 & 53 & 0.3 & 3.4 & 12 & 18 & 2 & 24 & 57 \\
\hline
\end{tabular}
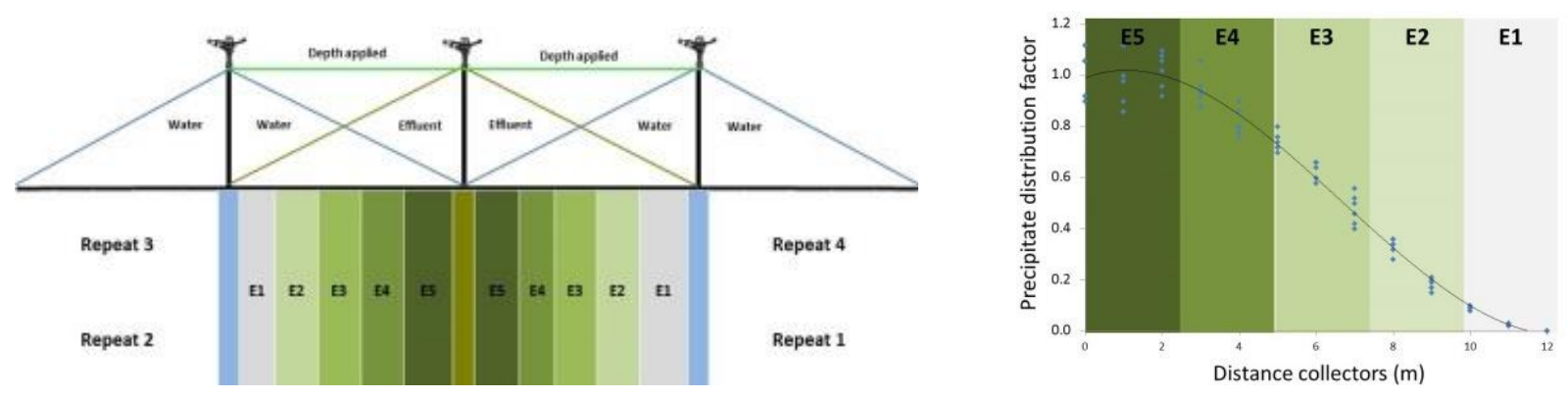

Fig 1. Experimental scheme showing the distribution of lines of gradual treated sewage effluent in water (left) and the distribution ratio of precipitation on the distance of irrigation lines (right).

Table 2. Mean climatic conditions during the experiment, in 2013 and 2014.

\begin{tabular}{|c|c|c|c|c|c|c|c|c|}
\hline \multirow[b]{2}{*}{ Year } & \multirow{2}{*}{ Season } & \multicolumn{3}{|c|}{ Temperature $\left({ }^{\circ} \mathrm{C}\right)$} & \multirow{2}{*}{$\mathrm{RH}(\%)$} & \multirow{2}{*}{$\begin{array}{l}\text { SR } \\
\left(\mathrm{MJ} \mathrm{m} \mathrm{m}^{-2} \mathrm{day}^{-1}\right)\end{array}$} & \multirow{2}{*}{$\begin{array}{l}\text { Precipitation } \\
(\mathrm{mm})\end{array}$} & \multirow{2}{*}{$\begin{array}{l}\text { ETo* } \\
(\mathrm{mm})\end{array}$} \\
\hline & & Min & Max & Mean & & & & \\
\hline \multirow[t]{5}{*}{2013} & Summer & 14.6 & 35.0 & 23.8 & 76.9 & $2,195.4$ & 748 & 487 \\
\hline & Fall-winter & 4.6 & 31.3 & 20.0 & 69.2 & $1,935.5$ & 221 & 388 \\
\hline & Spring & 5.4 & 35.9 & 22.8 & 63.6 & $2,130.1$ & 424 & 523 \\
\hline & Year & 8.2 & 34.1 & 22.2 & 69.9 & $2,087.0$ & 1,393 & 1,398 \\
\hline & Summer & 15.8 & 35.9 & 24.8 & 68.8 & $2,407.9$ & 348 & 584 \\
\hline \multirow[t]{3}{*}{2014} & Fall-winter & 8.4 & 33.7 & 20.8 & 62.8 & $2,072.6$ & 102 & 460 \\
\hline & Spring & 11.5 & 39.8 & 24.2 & 55.9 & $2,093.0$ & 271 & 572 \\
\hline & Year & 11.9 & 36.5 & 23.3 & 62.5 & $2,191.2$ & 721 & 1,616 \\
\hline
\end{tabular}

*SR: solar radiation; RH: relative humidity; ETo: reference crop evapotranspiration. Source: UNESP (2015).

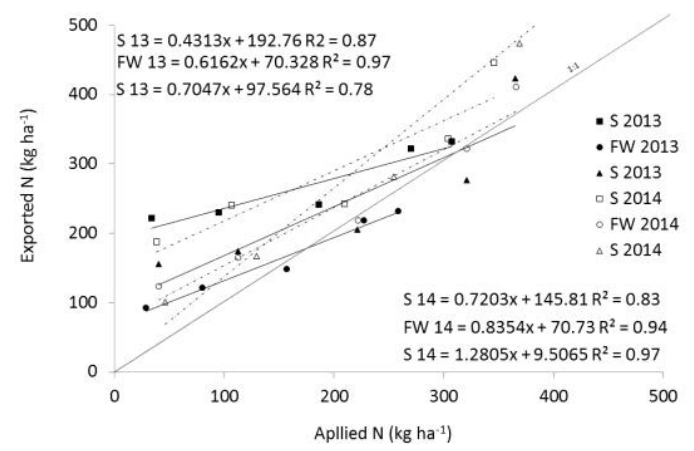

Fig 2. Extraction of $\mathrm{N}$ from the dry biomass of Brachiaria in summer (S), fall-winter (FW), and spring (S) in 2013 and 2014 , as a function of applied $\mathrm{N}$ via fertigation with treated sewage effluent.

Table 3. Seasonal and mean chemical attributes of the applied treated sewage effluent in 2013 and 2014.

\begin{tabular}{|c|c|c|c|c|c|c|}
\hline Elements* & Units & Summer & Fall-winter & Spring & Mean & Parameters \\
\hline $\mathrm{PH}$ & - & 6.7 & 7.2 & 7.1 & $7.0 \pm 0.3$ & $5-9^{a}$ \\
\hline EC & $\mathrm{dS} \mathrm{m}^{-1}$ & 0.44 & 0.49 & 0.42 & $0.46 \pm 0.01$ & $<3^{b}$ \\
\hline $\mathrm{NO}_{3}$ & $\mathrm{mg} \mathrm{L}^{-1}$ & 2.1 & 5.8 & 4.5 & $4.5 \pm 2.4$ & $<10^{\mathrm{c}}$ \\
\hline $\mathrm{NO}_{2}$ & $\mathrm{mg} \mathrm{L}^{-1}$ & 1.0 & 0.04 & 0.04 & $0.25 \pm 0.8$ & $<0.02^{\mathrm{C}}$ \\
\hline $\mathrm{NH} 3$ & $\mathrm{mg} \mathrm{L}^{-1}$ & 31.4 & 35.7 & 31.6 & $33.3 \pm 15.8$ & $1-40^{c}$ \\
\hline Ntotal & $\mathrm{mg} \mathrm{L}^{-1}$ & 44.3 & 57.8 & 51.7 & $52.9 \pm 7.0$ & - \\
\hline K & $\mathrm{mg} \mathrm{L}^{-1}$ & 25.3 & 19.1 & 17.2 & $20.3 \pm 7.2$ & $10-40^{c}$ \\
\hline$P$ & $\mathrm{mg} \mathrm{L}^{-1}$ & 1.3 & 1.0 & 1.0 & $1.1 \pm 0.4$ & $<2^{b}$ \\
\hline $\mathrm{Ca}$ & $\mathrm{mg} \mathrm{L}^{-1}$ & 9.3 & 15.9 & 21.2 & $15.5 \pm 6.4$ & $20-120^{c}$ \\
\hline Mg & $\mathrm{mg} \mathrm{L}^{-1}$ & 7.5 & 4.9 & 7.0 & $6.2 \pm 2.6$ & $10-50^{c}$ \\
\hline $\mathrm{Na}$ & $\mathrm{mg} \mathrm{L}^{-1}$ & 60.3 & 54.1 & 64.3 & $58.8 \pm 8.7$ & $50-250^{c}$ \\
\hline SAR & - & 20.0 & 16.7 & 17.8 & $18.0 \pm 2.9$ & $4.5-7.5^{c}$ \\
\hline
\end{tabular}

*pH: hydrogen ionic potential; EC: electrical conductivity; $\mathrm{NO}_{3}$ :nitrate; $\mathrm{NO}_{2}$ : nitrogen dioxide; $\mathrm{NH}$ : ammonia; Ntotal: to
sodium; SAR: sodium adsorption ratio. Source: ${ }^{B}$ Brazil (2011); ${ }^{\mathrm{b}}$ Ayers Westcot (1976); ${ }^{\mathrm{C}}$ Feigin, and Shalhevet Ravine (1991). 


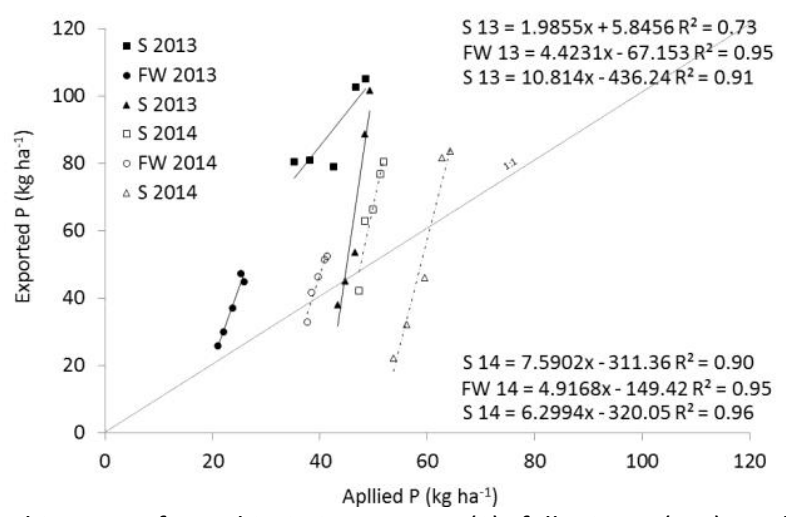

Fig 3. Extraction of $P$ from the dry biomass of Brachiaria in summer (S), fall-winter (FW), and spring (S) in 2013 and 2014 , as a function of applied $\mathrm{P}$ via fertigation with treated sewage effluent, supplemented with mineral $\mathrm{P}_{2} \mathrm{O}_{5}$.

Table 4. Annual and seasonal irrigation and nitrogen applied via treated sewage effluent, according to treatment, during 2013 and 2014.

\begin{tabular}{|c|c|c|c|c|c|c|c|}
\hline \multirow{3}{*}{ Year } & \multirow{3}{*}{ Season } & \multirow{3}{*}{$\begin{array}{l}\text { Irrigation } \\
(\mathrm{mm})\end{array}$} & \multicolumn{5}{|c|}{ Treatment } \\
\hline & & & E5 & $\mathrm{E} 4$ & E3 & E2 & E1 \\
\hline & & & --------- & $\left.a^{-1}\right)---$ & --- & & \\
\hline \multirow{4}{*}{2013} & Summer & 678 & 307 & 270 & 186 & 95 & 34 \\
\hline & Fall-winter & 500 & 258 & 227 & 156 & 80 & 28 \\
\hline & Spring & 675 & 365 & 321 & 221 & 112 & 40 \\
\hline & Total & 1,853 & 931 & 817 & 564 & 287 & 102 \\
\hline \multirow{4}{*}{2014} & Summer & 750 & 346 & 304 & 210 & 107 & 38 \\
\hline & Fall-winter & 661 & 366 & 321 & 222 & 113 & 40 \\
\hline & Spring & 842 & 420 & 369 & 255 & 130 & 46 \\
\hline & Total & 2,253 & 1,132 & 994 & 687 & 350 & 124 \\
\hline
\end{tabular}

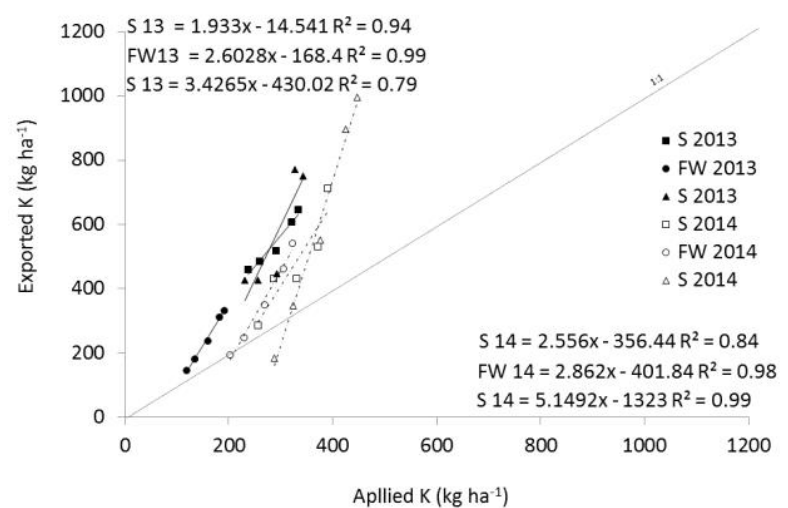

Fig 4. Extraction of $K$ from the dry biomass of Brachiaria in summer (S), fall-winter (FW), and spring (S) in 2013 and 2014 , as a function of applied $\mathrm{K}$ via fertigation with treated sewage effluent, supplemented with mineral $\mathrm{K}_{2} \mathrm{O}$.

Table 5. Mean Brachiaria dry biomass productivity $\left(\mathrm{kg} \mathrm{ha}^{-1}\right)$ during the seasons and each year in 2013 and 2014.

\begin{tabular}{llllllll}
\hline Year & Season & E5 & E4 & E3 & E2 & E1 & Mean \\
\hline \multirow{4}{*}{2013} & Summer & 18,997 & 18,413 & 17,243 & 16,460 & 15,861 & 17,395 \\
& Fall-winter & 9,613 & 9,467 & 7.513 & 5,868 & 5.367 & 7.566 \\
& Spring & 18,775 & 17,309 & 12.106 & 11,512 & 10,032 & 13,947 \\
& Total & 47,385 & 45,189 & 36,862 & 33,840 & 31,260 & - \\
& Summer & 18,515 & 16,567 & 13,291 & 13,312 & 10,976 & 14,532 \\
& Fall-winter & 14,435 & 12,579 & 10,456 & 8,801 & 7,688 & 10,792 \\
& Spring & 23,957 & 22.107 & 14,915 & 10,079 & 7,072 & 15,626 \\
& Total & 56,907 & 51,256 & 38,662 & 32,191 & 25,736 & - \\
\hline
\end{tabular}




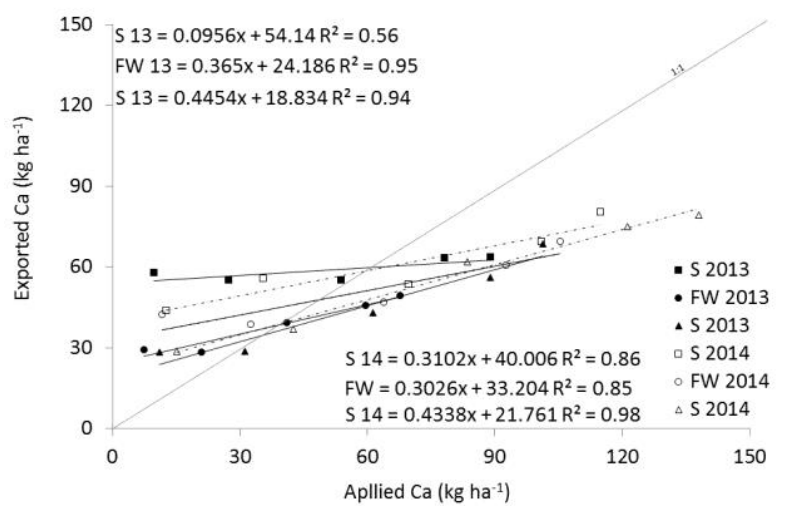

Fig 5. Extraction of Ca from the dry biomass of Brachiaria in summer (S), fall-winter (FW), and spring (S) in 2013 and 2014 , as a function of applied Ca via fertigation with treated sewage effluent.

Table 6. Mean $\mathrm{N}$ concentration in Brachiaria biomass ( $\mathrm{kg} \mathrm{t}^{-1}$ ) during summer, fall-winter, and spring in 2013 and 2014.

\begin{tabular}{lllllll}
\hline \multirow{2}{*}{ Season } & \multicolumn{5}{c}{ Treatment } \\
\cline { 2 - 6 } & E5 & E4 & E3 & E2 & E1 \\
\hline Summer & 20.8 & 18.9 & 16.1 & 16.0 & 15.5 & $17.5 \pm 3.1$ \\
Fall winter & 26.3 & 24.4 & 20.3 & 19.7 & 16.7 & $21.5 \pm 3.7$ \\
Spring & 23.5 & 18.7 & 17.9 & 15.8 & 14.9 & $18.2 \pm 3.5$ \\
Mean & 23.5 & 20.7 & 18.1 & 17.2 & 15.7 & - \\
\hline
\end{tabular}

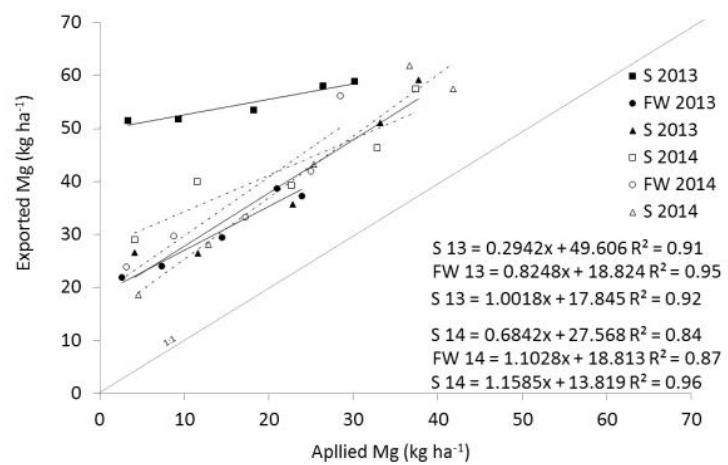

Fig 6. Extraction of Mg from the dry biomass of Brachiaria in summer (S), fall-winter (FW), and spring (S) in 2013 and 2014 , as a function of applied Mg via fertigation with treated sewage effluent.

Table 7. Average P extraction from Brachiaria $\left(\mathrm{kg} \mathrm{t}^{-1} \mathrm{BS}\right)$ in summer, fall-winter, and spring.

\begin{tabular}{|c|c|c|c|c|c|c|}
\hline \multirow{2}{*}{ Season } & \multicolumn{5}{|c|}{ Treatment } & \multirow{2}{*}{-Average } \\
\hline & E5 & E4 & E3 & E2 & E1 & \\
\hline Summer & 4.9 & 5.1 & 4.8 & 4.8 & 4.5 & $4.8 \pm 0.5$ \\
\hline Fall winter & 4.2 & 4.5 & 4.7 & 4.9 & 4.6 & $4.6 \pm 0.5$ \\
\hline Spring & 4.5 & 4.4 & 3.8 & 3.6 & 3.5 & $3.9 \pm 0.8$ \\
\hline Average & 4.5 & 4.7 & 4.4 & 4.4 & 4.2 & - \\
\hline
\end{tabular}

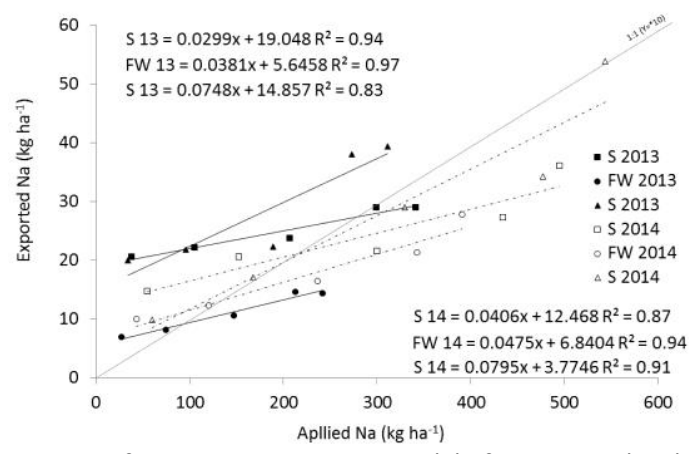

Fig 7. Extraction of $\mathrm{Na}$ from the dry biomass of Brachiaria in summer (S), fall-winter (FW), and spring (S) in 2013 and 2014 , as a function of applied Na via fertigation with treated sewage effluent. 
Table 8. Average $\mathrm{K}$ extraction from Brachiaria $\left(\mathrm{kg} \mathrm{t}^{-1} \mathrm{BS}\right)$ in the summer, fall-winter and spring.

\begin{tabular}{lllllll}
\hline Season & \multicolumn{7}{c}{ Treatment } & Everage \\
\cline { 2 - 7 } & E5 & E4 & E3 & E2 & E1 & $31.7 \pm 3.4$ \\
Summer & 36.3 & 32.5 & 31.3 & 31.0 & 27.5 & $31.8 \pm 5.3$ \\
Fall winter & 36.0 & 34.9 & 32.5 & 29.6 & 26.1 & $38.1 \pm 5.2$ \\
Spring & 40.8 & 42.5 & 37.0 & 35.8 & 34.3 & - \\
Average & 37.7 & 36.6 & 33.6 & 32.1 & 29.3 & \\
\hline
\end{tabular}

Table 9. Average extraction of Ca from Brachiaria $\left(\mathrm{kg} \mathrm{t}^{-1} \mathrm{BS}\right)$ in the summer, fall-winter, and spring.

\begin{tabular}{|c|c|c|c|c|c|c|}
\hline \multirow{2}{*}{ Season } & \multicolumn{5}{|c|}{ Treatment } & \multirow{2}{*}{-Average } \\
\hline & $\mathrm{E5}$ & E4 & E3 & E2 & E1 & \\
\hline Summer & 3.9 & 3.8 & 3.6 & 3.8 & 3.8 & $3.8 \pm 0.4$ \\
\hline Fall winter & 5.0 & 4.8 & 4.9 & 4.6 & 5.5 & $5.0 \pm 0.6$ \\
\hline Spring & 3.5 & 3.3 & 3.9 & 3.1 & 3.5 & $3.4 \pm 0.5$ \\
\hline Average & 4.1 & 4.0 & 4.1 & 3.8 & 4.3 & - \\
\hline
\end{tabular}

Table 10. Average extraction of Mg from Brachiaria ( $\left.\mathrm{kg} \mathrm{t}^{-1} \mathrm{BS}\right)$ in the summer, fall-winter, and spring.

\begin{tabular}{|c|c|c|c|c|c|c|}
\hline \multirow{2}{*}{ Season } & \multicolumn{5}{|c|}{ Treatment } & \multirow{2}{*}{-Average } \\
\hline & E5 & E4 & E3 & $\mathrm{E} 2$ & E1 & \\
\hline Summer & 3.1 & 3.0 & 3.0 & 3.1 & 3.0 & $3.0 \pm 0.2$ \\
\hline Fall winter & 3.9 & 3.7 & 3.6 & 3.7 & 3.6 & $3.7 \pm 0.7$ \\
\hline Spring & 2.8 & 2.9 & 2.9 & 2.6 & 2.7 & $2.8 \pm 0.3$ \\
\hline Average & 3.3 & 3.2 & 3.2 & 3.1 & 3.1 & - \\
\hline
\end{tabular}

Table 11. Average extraction of $\mathrm{Na}$ from Brachiaria $\left(\mathrm{kg} \mathrm{t}^{-1} \mathrm{BS}\right)$ in the summer, fall-winter, and spring.

\begin{tabular}{lllllll}
\hline \multirow{2}{*}{ Season } & \multicolumn{5}{c}{ Treatments } \\
\cline { 2 - 7 } Summer & E5 & E4 & E3 & E2 & E1 & Average \\
Fall winter & 1.7 & 1.6 & 1.5 & 1.5 & 1.3 & $1.5 \pm 0.2$ \\
Spring & 1.7 & 1.6 & 1.5 & 1.4 & 1.3 & $1.5 \pm 0.2$ \\
Average & 2.2 & 1.9 & 1.9 & 1.8 & 1.7 & $1.9 \pm 0.3$ \\
\hline
\end{tabular}

of the water requirement of the crop. Those authors concluded that even when excess $\mathrm{K}$ was applied, nutrients did not accumulate due to the amount contributed by the crop, thus reducing the environmental risks due to the leaching of nutrients to the water table.

There was a gradual effect of foliar $\mathrm{K}$ due to the application of TSE, as well as in the extraction of nutrients. The highest $K$ extraction by Brachiaria during spring in the second year, and was $122 \%$ higher than that applied (Fig 4). In the second year, there was a higher concentration of foliar $\mathrm{K}$ and higher productivity of dry biomass, resulting in greater nutrient extraction.

Even with supplemental mineral fertilization with $\mathrm{K}$, a gradual effect was observed following TSE application (Table 8). In addition to fertilizer application, there was a moderate contribution from leaf residues in the area.

$\mathrm{K}$ was the most extracted element in the soil by the crop, with 1,694 and 2,205 $\mathrm{kg} \mathrm{ha}^{-1}$ obtained with the E5 treatment in 2013 and 2014, respectively; N was the second most extracted element at being 1,045 kg ha ${ }^{-1}$ in 2013 and 1,501 $\mathrm{kg} \mathrm{ha}^{-1}$ in 2014. Similar results were obtained by Costa et al. (2010). In C4 plants, Na may partially replace K (INOCÊNCIO et al., 2014), which justifies the high absorption and extraction of $\mathrm{K}$ by Brachiaria.

Similar results were reported by Primavesi et al. (2006) who obtained $\mathrm{K}$ as a macronutrient extracted by most crops, and $34.8 \mathrm{~kg}$ of $\mathrm{K} \mathrm{t}^{-1}$ of dry biomass. Among the macronutrients evaluated by Coelho and Martins (2004), K was also extracted by Brachiaria, at $23.2 \mathrm{~kg}$ of $\mathrm{K} \mathrm{t}^{-1}$ of dry biomass.

The balance of $\mathrm{Ca}$ in the soil was negative for treatments with lower application of TSE (E2 and E1). The highest Ca extraction by Brachiaria occurred in the summer of the second year, with a balance $42 \%$ higher than that applied (Fig 5). The greatest Ca deficiency occurred with the E1 treatment in the summer of 2013.

In addition to Ca applied via TSE, there was the removal of soil, which originated from the formation of soil and residues from predecessor crops.

There was greater $\mathrm{Ca}$ extraction by the crop in fall-winter (Table 9). This was due to the reduced development of the crop and competition for nutrients. Similar results were obtained by Primavesi et al. (2006) with extraction of Ca at $3.9 \mathrm{~kg} \mathrm{t}^{1}$ BS. However, Monteiro et al. (1995) cultivated Brachiaria with $\mathrm{Ca}$ omission, and obtained higher productivity of dry biomass, number of tillers, and height of plants. The highest extraction of Mg by Brachiaria occurred in the spring with treatment $\mathrm{E} 5$ in the second year and was $37.5 \%$ higher than the applied concentration (Fig 6).

$\mathrm{Mg}$ extraction by the crop followed a similar pattern to $\mathrm{Ca}$ and decreased in the order fall-winter, summer, and spring (Table 10). There was no effect per treatment, which means that the crop reached its nutrient extraction potential at that time. Similar results were obtained by Primavesi et al. (2006) with extraction of $\mathrm{Mg}$ at $3.6 \mathrm{~kg} \mathrm{t}^{-1}$ BS. Na was the only 
element that was extracted at higher levels by Brachiaria in relation to application at any time. Na was extracted at the highest levels by Brachiaria in the spring of the second year (Fig 7). The foliar concentration of Na was low $\left(1.7 \pm 0.2 \mathrm{~g} \mathrm{~kg}^{-}\right.$ $\left.{ }^{1}\right)$; this was similar over time and there was no effect of the doses applied. The average extraction of $\mathrm{Na}$ was $1.6 \mathrm{~kg} \mathrm{ha}^{-1}$ ton of dry biomass produced by the crop. As discussed above, $\mathrm{Na}$ may have been partially absorbed as $\mathrm{K}$. Contrasting results were presented by Coelho and Martins (2004) whereby the grass Brachiaria extracted $\mathrm{Na}$ at $52.5 \mathrm{~kg}$ $\mathrm{t}^{-1} \mathrm{BS}$.

Silva et al. (2012) evaluated the chemical production of mombaça grass cultivated in different effluent sludges from the primary treatment of sanitary sewage, based on sodium $\left(0,75,150,225\right.$ and $\left.300 \mathrm{~kg} \mathrm{ha}^{-1} \mathrm{Na}\right)$ and increase with a content of $22.8 \mathrm{~g} \mathrm{~kg}^{-1}$. A gradual effect of $\mathrm{Na}$ leaf was observed only from the second epoch.

Of all minerals, $\mathrm{Na}$ was applied at the highest level and extracted at the lowest level by the crop. Na extraction by the crop occurred similarly between the seasons and the treatments (Table 11).

There was low Na uptake by forage $\left(<2 \mathrm{~g} \mathrm{~kg}^{-1}\right)$. The mobility of $\mathrm{Na}$ constant precipitation in the region $\left(>1,200 \mathrm{~mm}^{-}\right.$ $\left.{ }^{1}\right)$, resulted in Na leaching.

High absorption of the other nutrients by $B$. brizantha resulted in split of the fermentation, reduced leaching potential, and increased nutrient efficiency of the crop, thereby reducing environmental impacts. These results demonstrate the usefulness of $B$. brizantha in purification of waste water, thus, increasing its agri-environmental, social, and economic importance.

\section{Materials and methods}

The study was conducted during 2013 and 2014 at the Faculty of Agrarian and Veterinary Sciences (FCAV-UNESP), in Jaboticabal, SP, Brazil (latitude 21 $1^{\circ} 14^{\prime} 41.9^{\prime \prime S}$ and longitude $\left.48^{\circ} 16^{\prime} 25.2^{\prime \prime} \mathrm{W}\right)$. We used TSE from the municipal sewage treatment plant (STP) located near the experimental area. Treatment performed in this STP consists of a mixed system (aerobic and anaerobic) composed of an upflow anaerobic digester and facultative lagoons. This plant collects sewage from Jaboticabal, with an average flow of $202 \mathrm{~L}$ inhab $^{-1}$. The city has near 71,662 inhabitants, an area of $707 \mathrm{~km}^{2}$, and population density of 101.4 inhabitants $\mathrm{km}^{-2}$ (IBGE, 2010).

The soil of the experimental area is classified as a typical eutrophic Red Latosol, with a clayey texture, moderate, kaolinitic apoférrico, high iron content, and smooth and wavy relief (EMBRAPA, 2013), with a slope of $5 \%$, characterized by a very clayey texture $(>50 \%)$, high iron content, good fertility, and soft relief (Table 1).

The climate of the region is humid subtropical, Aw, according to the Köppen classification, with dry and mild winters, and hot and rainy summers. The weather in 2013 was characterized by conditions similar to normal in the region, with a mean annual temperature of $22.2^{\circ} \mathrm{C}$, relative humidity of $69.9 \%$, solar radiation of $17.5 \mathrm{MJ} \mathrm{m}^{-2} \mathrm{day}^{-1}$, and precipitation close to reference evapotranspiration (ETo) (Table 2). The second experimental year was dryer, with precipitation of $721 \mathrm{~mm}$ and ETo of $1,616 \mathrm{~mm}$, mean temperature of $23.3^{\circ} \mathrm{C}$, solar radiation of $18.3 \mathrm{MJ} \mathrm{m}^{-2} \mathrm{day}^{-1}$, and relative humidity of $62.5 \%$. The experiment was conducted in an area of $288 \mathrm{~m}^{2}$ consisting of 20 plots of 14.4 $\mathrm{m}^{2}, 2.4 \mathrm{~m}$ wide, and $6 \mathrm{~m}$ long. A uniform distribution of the irrigation and gradual distribution of TSE was obtained using a triple line source sprinkler system (LAUER, 1983), with five treatments, in four replicates, and the following fractions of the effluent in water: $\mathrm{E} 5=1.0 ; \mathrm{E} 4=0.87 ; \mathrm{E} 3=0.6 ; \mathrm{E} 2=0.31$ and E1 $=0.11$ (Fig 1). Monthly samples of TSE were collected for the analysis of nitrogen concentration. At the end of each season, complete nutrient analyses were performed (Table 3) using the APHA method (2005).

Irrigation was applied two to three times per week, at a depth determined by the crop nutritional needs or by the water demand in the E3 treatment, whichever was higher. The nutritional need was estimated as described by Vilela et al. (1998), supplying $15,3.5$, and $18 \mathrm{~kg} \mathrm{ha}^{-1}$ of $\mathrm{N}, \mathrm{P}$ and $\mathrm{K}$ per ton of dry biomass harvested over 28 days. The water demand was calculated using the FAO 56 method; the unit crop coefficient and reference evapotranspiration were calculated using local meteorological data. Due to the low concentration of $P$ and $K$ in TSE, these were supplemented with mineral fertilization. Fertilizers were applied according to the crop needs in each cutting cycle ( 28 days).

Dry forage biomass was determined from harvests made every 28 days, from Feb 5, 2013 to Jan 6, 2015, with eight harvests in the summer, 10 in the fall-winter, and eight in the spring. Three random replicates of $0.25 \mathrm{~m}^{2}$ were harvested per experimental plot at a height of $15 \mathrm{~cm}$. The forage was homogenized, and a sample was taken, weighed, and then oven dried with forced air circulation at $65^{\circ} \mathrm{C}$ to a constant weight (LACERDA et al., 2009).

The macro and micro nutrients in forage were qualitatively evaluated in each season as proposed by Bataglia et al. (1983). The extraction of soil nutrients was calculated as described by Costa et al. (2010):

$N e=N f D B$

Where;

Ne: Extracted nutrient $\left(\mathrm{kg} \mathrm{ha}^{-1}\right)$;

$\mathrm{Nf}$ : Biomass nutrient concentration $\left(\mathrm{g} \mathrm{kg}^{-1}\right)$; and DB: Dry forage biomass $\left(\mathrm{t} \mathrm{ha}^{-1}\right)$.

\section{Conclusion}

The most pronounced effects in terms of dry biomass yield of $B$. brizantha and nutrient extraction were obtained with the higher doses of TSE. Macronutrient extractions were higher for $\mathrm{K}$ and $\mathrm{N}$, followed by $\mathrm{P}, \mathrm{Ca}, \mathrm{Mg}$, and $\mathrm{Na}$. The deficiency in the soil balance is not a low leaching of the same ones, since the extraction was superior to the amount used, except for $\mathrm{Na}$. Because of the responses in productivity and nutrient extraction of the soil by $B$. brizantha as a function of TSE fertilization, it is proposed that future studies will include an increase in fertilizer application.

\section{Acknowledgments}

We thank the Support of the São Paulo Research Foundation (FAPESP) for the Grant \#: 2012/12923-3 and Scholarship \#:2013/00362 and also the Autonomous Water and Sewer Service of Jaboticabal - SAAEJ for the effluent availability. 


\section{References}

American Public Health Association (2005) Standard methods for the examination of water and wastewater. 21st edition, Washington.

Andrioli I, Centurion JF (1999) Levantamento detalhado dos solos da Faculdade de Ciências Agrárias e Veterinárias de Jaboticabal. Congresso Brasileiro de Ciência do Solo, 27, Brasília, 1999. Sociedade Brasileira de Ciência do Solo, 32 (CD-ROM).

Ayers RS, Westcot DW (1976) Calidad del agua para la agricultura. Roma: FAO, 174. (Estudios FAO: Riegos y Drenajes, 29).

Bataglia OC, Furlani AMC, Teixeira JPF, Furlam PR, Gallo JR (1983) Método de análise química de plantas. Boletim Técnico 78. Campinas: IAC, 48.

Blum J, Melfi AJ, Montes CR (2012) Nutrição mineral da cana-de-açúcar irrigada com efluente de esgoto tratado, em área com aplicação de fosfogesso. Pesq Agropec Bras. 47(4):563-602.

Brasil. Ministério do Meio Ambiente. Conselho Nacional do Meio Ambiente. Resolução N.430, de 13 de maio de 2011. Disponível em: <http://www.mma.gov.br>. Acesso em: 03 Jan. 2017.

Coelho AM, Martins CE (2004) Estado da arte da fertirrigação em pastagem no Brasil. Fertilidade do solo para pastagens produtivas. Simpósio sobre manejo de pastagens. Ed.: Carlos Guilherme Silveira Pedreira, José Carlos de Moura e Vidal Pedroso de Faria. Piracicaba: FEALQ. 480.

Costa KA de P, Faquin V, Oliveira IP de, Severiano E da C, Simon GA, Carrijo MS (2009) Extração de nutrientes do capim-marandu sob doses e fontes de nitrogênio. Revista Brasileira de Saúde e Produção Animal. 10(4):801-812.

Costa KA de P, Oliveira IP de, Severiano E da C, Sampaio F de MT, Carrijo MS, Rodriguês CR (2010) Extração de nutrientes pela fitomassa de cultivares de Brachiaria brizantha sob doses de nitrogênio. Ciências Animal Brasileira. 11(2):307-314.

Embrapa (2013) Empresa Brasileira de Pesquisa Agropecuária. Sistema brasileiro de classificação de solos. $3^{\text {rd }}$ edition: Brasília. 353.

Faria RT de, Caramori PH, Chibana EY, Brito LR de S, Nakamura AK, Ferreira AR (2002) Clima - programa computacional para organização e análise de dados meteorológicos. Boletim Técnico 66. Londrina: IAPAR, 29.

Feigin A, Ravina I, Shalhevet J (1991) Irrigation with treated sewage effluent: management for environmental protection. Berlin: Springer-Verlag, 224.

Fonseca AF da, Melfi AJ, Monteiro FA, Mones CR, Almeida VV de, Herpin U (2007) Treated sewage efluente as a source of water and nitrogen for Tifton 85 bermudagrass. Agr Water Manage. 87(1):329-336.

Inocêncio MF, Carvalho JG de, Furtini Neto AE (2014) Potássio, sódio e crecimento inicial de espécies florestais sob substituição de potássio por sódio. Revista Árvore. 38(1):113-123.

Instituto Brasileiro de Geografia e Estatística (2010) Censo demográfico 2010. Brasília: IBGE. Disponível em: <www.ibge.org.br>. Acesso em: 03 Jan 2017.

Lacerda MJR, Freitas KR, Silva JW (2009) Determinação da matéria seca de forrageiras pelos métodos de micro-ondas e convencional. Biosci J. 25(3):185-190.
Lauer DA (1983) Line source sprinkler systems for experimentation with sprinkler applied nitrogen fertilizers. Soil Sci Soci Amer J. 47(1):124-128.

Monteiro FA, Ramos AKB, Carvalho DD de, Abreu JBR de, Daiub JAS, Silva JEP da, Natale W (1995) Cultivo de Brachiaria brizantha Stapf. cv. Marandu em solução nutritiva com omissões de macronutrientes. Scientia Agrícola. 52(1):135-141.

Primavesi AC, Primavesi O, Corrêa L de A, Silva AG da, Cantarella H (2006) Nutrientes na fitomassa de capimmarandu em função de fontes de nitrogênio. Ciência Agrotecnologia. 30(3):562-568.

Rodriguês D de C (2004) Produção de forragem de cultivares de Brachiaria brizantha (Hochst. Ex ${ }^{\mathrm{a}}$ Rich.) Stapf e modelagem de respostas produtivas em função de variáveis climáticas. Dissertação de Mestrado. Escola Superior de Agricultura Luiz de Queiroz, 94.

Serafim RS, Galbiatti JA (2012) Efeito da aplicação de água residuária de suinocultura na Brachiaria brizantha cv. Marandu. Revista Colombiana de Ciência Animal. 4(1):185203.

Silva JGD, Matos AT, Borges AC, Previero CA (2012) Composição químico-bromatológica e produtividade do capim-mombaça cultivado em diferentes lâminas de efluente do tratamento primário de esgoto sanitário. Revista Ceres. 59(5):606-613.

Universidade Estadual Paulista. Dados climáticos diários. Disponível em: <http://www.fcav.unesp.br/>. Acesso em: 08 dez. 2016.

Vilela L, Soares WV, Sousa DMG de, Macedo MCM (1998) Calagem e adubação para pastagens na região do cerrado. Planaltina: Embrapa Cerrado. Circular Técnico. 37. 16. 